\title{
1961 2015年中国气候干湿状况的时空分异
}

\author{
苑全治 ${ }^{1,2}$, 吴绍洪 $3,4^{*}$, 戴尔阜 ${ }^{3,4}$, 赵东升 ${ }^{3}$, 张学儒 ${ }^{5,6}$, 任平 1,2
}

1. 四川师范大学西南土地资源评价与监测教育部重点实验室, 成都 610068;

2. 四川师范大学地理与资源科学学院, 成都 610101;

3. 中国科学院地理科学与资源研究所, 中国科学院陆地表层格局与模拟重点实验室, 北京 100101 ;

4. 中国科学院大学, 北京 100049 ;

5. 重庆交通大学建筑与城市规划学院, 重庆 400074;

6. 河北经贸大学公共管理学院, 石家庄 050061

*通讯作者, E-mail: wush@igsnrr.ac.cn

收稿日期: 2017-04-23; 接受日期: 2017-08-17; 网络版发表日期: 2017-09-18

国家自然科学基金重点项目(批准号: 41530749)、国家自然科学基金青年项目(批准号: 41501202、41701100)和四川省教育厅科技项目(编 号: 15ZB0023)资助

摘要 气候干湿状况由降水量和潜在蒸散 $E T_{\mathrm{o}}$ 共同决定, 是表征区域环境特点的重要指标. 本研究基于气象 站实测数据, 首先利用FAO56 Penman-Monteith模型计算 $E T_{\mathrm{o}}$, 然后采用年干燥度指数 $K\left(\right.$ 年 $E T_{\mathrm{o}}$ 与降水量之比)研 究了1961 2015年中国陆地气候干湿状况的时空分异规律, 并讨论了干湿变化的主导气候因子, 结果显示: 秦岭淮河一线年降水量和 $E T_{\mathrm{o}}$ 大致相等 $(K \approx 1.0)$, 该线以南、横断山脉以东的大部分区域降水量高于 $E T_{\mathrm{o}}(K<1.0)$, 气候 湿润; 而西北内陆地区降水量远小于 $E T_{\mathrm{o}}(K \geq 4.0)$, 气候干燥. 全国总体千湿状况围绕平均值上下波动, 且线性变 化趋势不显著, 但其中存在一段跨度约10年的相对湿润时期(1987 1996年). 全国总体干湿状况在3年、7 8年、 11 年和26 28年的时间尺度上表现出了较强的周期性。气候干湿变化趋势及周期性的区域差异明显, 其中西北 和青藏高原西部等地区湿润程度增加幅度较大, 而云贵高原、四川盆地和黄土高原等地区干燥程度增加幅度 较大, 但区域干湿变化的线性趋势大多不显著. 大部分地区气候干湿变化在8 14年的周期上表现出较强的节律 性. 降水量是大部分区域千湿变化的最重要影响因子,特别在中国北方地区气候干湿变化与降水量高度相关.

关键词气候干湿状况, 干燥度指数, 潜在蒸散, 气候变化, 时空分异, 中国

\section{1 引言}

近五六十年来中国气候的变暖速率高于全球平 均值, 年降水量变化的区域差异明显(第三次气候变化 国家评估报告, 2015). 显著的气候变化影响了中国植 物物候(方修琦和陈发虎, 2015)、自然生态系统脆弱
性(苑全治等, 2016)以及气候变化风险格局(吴绍洪等, 2017)等.气候干湿变化是气候变化的重要组成部分, 是大气水分循环的体现, 对于地表辐射平衡(张强等, 2014)、水热过程(岳平等, 2015)以及农业生产潜力格 局(王铮等, 2016)等有重大影响. 近年来, 随着气候变 化研究的深入, 中国及典型区域的气候干湿状况正受

中文引用格式: 苑全治, 吴绍洪, 戴尔阜, 赵东升, 张学儒, 任平. 2017. 1961 2015年中国气候干湿状况的时空分异. 中国科学: 地球科学, 47: 1339-1348, doi: 10.1360/N072017-00025

英文引用格式: Yuan Q Z, Wu S H, Dai E F, Zhao D S, Zhang X R, Ren P. 2017. Spatio-temporal variation of the wet-dry conditions from 1961 to 2015 in China. Science China Earth Sciences, 60: 2041-2050, doi: 10.1007/s11430-017-9097-1 
到越来越多的关注.

杨建平等(2002)利用干燥度指数(潜在蒸散 $E T_{0}$ 与降 水量 $P$ 之比) 探讨了中国1951 1999年气候干湿区划界 线的 10 年际波动, 该文较早的采用了综合气候指数来反 映全国的干湿状况. 吴绍洪等(2005)和尹云鹤等(2005) 根据中国实际情况修改了FAO56 Penman-Monteith模 型中的净辐射 $\left(R_{n}\right)$ 计算经验系数, 并基于此利用干燥 度指数分别研究了中国1971 2000年气候干湿状况和 区域差异. 申双和等(2009)对比了湿润度指数 $\left(P\right.$ 与 $E T_{\text {。 }}$ 之比)和传统的降水量两种指标在干湿区划中的差异, 发现综合了多气候要素的湿润度指数能更好地表征 中国的干湿状况. 气候干湿状况是中国北方干旱、半 干旱地区的关键环境因素, 王菱等(2004)首次采用湿 润度指数对北方地区进行干湿气候区划, 并将其与谢 氏干燥度和降水量指标划分的干湿区进行对比, 证明 了湿润度指数在北方干湿区划中的可行性. 马柱国 (2005)利用地表水分收支指数分析了北方干湿演变规 律及其与区域增暖的可能联系. 青藏高原是世界上 气候独特的自然地理单元, 毛飞等(2008)比较了 5 种指 标在青藏高原的适用性, 最后利用湿润度指数分析了 1961 2006青藏高原各气候区干湿状况及其界线的动 态变化.

可见, 目前的研究大多倾向使用综合了多个气候 要素的指数来衡量干湿状况. 但由于研究目标不相同, 研究内容也各有侧重, 有的偏重空间分异研究, 有的 偏重时序上的趋势分析, 对于全国气候干湿状况的时 空分异规律认识大多不够全面, 且近期鲜有关于全国 尺度上的干湿状况讨论. 而越长的时间序列数据往往 越有利于气候变化规律的研究, 随着近十几年来观测 数据的积累, 使更长时间跨度上的气候干湿变化研究 成为可能. 本文将基于全国气象台站数据, 利用干燥 度指数分析中国1961 2015年气候干湿状况的时空变 化特征, 包括平均干湿状况空间格局、气候干湿变化 趋势及周期性, 并探讨气候干湿变化的主导因子, 为 更加全面深入地了解中国气候干湿状况时空分异规 律提供科学依据.

\section{2 数据与方法}

\section{1 数据}

本文所用基础气象数据来源于中国气象局气象
数据中心, 包括1961 2015年全国基准、基本气象站 点的最低气温、最高气温、降水量、风速、相对湿 度和日照时数的日值数据.

\section{2 干燥度指数计算}

科学家先后提出了多种定量化的指数来表示气 候的干湿状况, 其中有很多是发展于道库恰耶夫(V. V. Dokutchaev)和维索茨基(G. N. Vyssotsky)在20世纪初提 出的降水和蒸发之比(王延禄, 1990). 如Holdridge(1947) 的可能蒸散率、Thornthwaite(1948) 的湿润指数以及 Budyko(1974)的辐射干燥指数等. 上述指数均基于大 气水分收支的两个分量, 即降水量 $(P)$ 和潜在蒸散量 $\left(E T_{0}\right)$, 本研究采用干燥度指数作为衡量干湿状况的指 标:

$$
K=\frac{E T_{\mathrm{o}}}{P},
$$

式中, $K$ 为干燥度指数, $E T_{\mathrm{o}}$ 为潜在蒸散量 $(\mathrm{mm}), P$ 为降 水量 $(\mathrm{mm})$.

干燥度指数计算的关键是 $E T_{\mathrm{o}}$, 目前运用较广的是 Penman-Monteith模型. 该模型最初由Penman(1948)基 于空气动力学和能量平衡理论提出, Monteith(1981)对 Penman模型进行了修改, 不仅继承了原模型综合多个 气候因子的优势, 还引入了表面阻力的影响, 考虑了植 被生理特征, 修改后的模型(即Penman-Monteith模型) 具有良好的理论基础和明确的物理意义, 得到了广泛 应用, 其中不乏在复杂地形区的研究 (Gurtz等, 1999; Fisher等, 2005). 联合国粮农组织在该模型基础上又进 一步修改, 修改后的模型(FAO56 Penman-Monteith模 型)对不同气候条件下的 $E T_{0}$ 计算均较为准确, 被推荐 为计算蒸散发的首选方法(Allen等, 1998), 公式如下:

$$
E T_{\mathrm{o}}=\frac{0.408 \Delta\left(R_{n}-G\right)+\gamma \frac{900}{T+273} U_{2}\left(e_{s}-e_{a}\right)}{\Delta+\gamma\left(1+0.34 U_{2}\right)},
$$

式中, $E T_{\mathrm{o}}$ 为日潜在蒸散量 $(\mathrm{mm}), G$ 为土壤热通量 $\left(\mathrm{MJ} \mathrm{m}^{-2} \mathrm{~d}^{-1}\right), T$ 为日平均气温 $\left({ }^{\circ} \mathrm{C}\right), U_{2}$ 为 $2 \mathrm{~m}$ 高处的风 速 $\left(\mathrm{m} \mathrm{s}^{-1}\right), e_{s}$ 为平均饱和水汽压 $(\mathrm{kPa}), e_{a}$ 为实际水汽压 $(\mathrm{kPa}), \gamma$ 为干湿常数 $\left(\mathrm{kPa}{ }^{\circ} \mathrm{C}^{-1}\right), \Delta$ 为饱和水汽压曲线斜 率 $\left(\mathrm{kPa}{ }^{\circ} \mathrm{C}^{-1}\right), R_{n}$ 为太阳净辐射 $\left(\mathrm{MJ} \mathrm{m}^{-2} \mathrm{~d}^{-1}\right)$. Yin等 (2008) 修正了该模型中计算太阳净辐射 $\left(R_{n}\right)$ 的经验参数 (式 (2)), 使其能够更好的适应中国气候特点, 修正后的计 
算方法已经被用于全国气候区划(郑景云等, 2010):

$$
\begin{aligned}
R_{n}= & 0.77 \times\left(0.2+0.79\left(\frac{n}{N}\right)\right) R_{s o}-\sigma\left(\frac{T_{\max , k}^{4}+T_{\min , k}^{4}}{2}\right) \\
& \times\left(0.56-0.25 \sqrt{e_{a}}\right)\left(0.1+0.9\left(\frac{n}{N}\right)\right),
\end{aligned}
$$

式中, $\sigma$ 为Stefan-Boltzmann常数 $\left(4.903 \times 10^{-9} \mathrm{MJ} \mathrm{K}^{-4} \mathrm{~m}^{-2}\right.$ $\left.\mathrm{d}^{-1}\right), T_{\max , k}$ 为日最高气温绝对温标 $(\mathrm{K}), T_{\min , k}$ 为日最低 气温绝对温标 $(\mathrm{K}), n$ 为实际日照时数 (h), $N$ 为可照时数 $(\mathrm{h}), R_{s o}$ 为晴天太阳总辐射 $\left(\mathrm{MJ} \mathrm{m}^{-2} \mathrm{~d}^{-1}\right) . E T_{0}$ 计算公式中 其他参量的计算方法参考Allen等(1998).

\section{3 小波变换}

小波是长度有限、平均值为 0 的特殊波形. 通过 将小波函数 $\varphi(t)$ 平移 $\tau$ 后, 再在不同尺度 $a$ 下与待分析 函数 $f(t) \in L^{2}(R)$ 作内积, 可以达到分解原函数的目的, 即 小波变换(wavelet transform):

$W_{f}(a, \tau)=\left\langle f(t), \varphi_{a, \tau}(t)\right\rangle=\frac{1}{\sqrt{a}} \int_{R} f(t) \varphi\left(\frac{t-\tau}{a}\right) \mathrm{d} t$,

式中, $W_{f}(a, \tau)$ 为小波系数, $a$ 为尺度因子, $\tau$ 为平移因子.

Morlet小波是高斯包络下的单频率复正弦函数, 具有很好的时域和频域局部性, 常被用于区域气候的 多尺度时频特征研究. 本研究将利用Morlet 小波研究 1961 2015年中国陆地气候干湿变化的周期特征, 为 此需要对小波系数进行方差分析:

$$
W p(a)=\int_{-\infty}^{+\infty}\left|W_{f}(a, b)\right|^{2} \mathrm{~d} b,
$$

式中, $W p(a)$ 为小波方差, $W_{f}(a, b)$ 为 $f(t)$ 在位置 $b$ 、尺度 $a$ 上的小波系数. 小波方差的大小表示不同时间尺度上 气候干湿变化节律性的强弱, 小波方差的极大值所对 应的时间尺度可视为区域干湿变化节律性显著的周 期.

\section{4 相关分析}

本文将运用相关分析方法来研究干湿状况与各 个气候因子之间的相关关系, 相关关系的强弱可通过 皮尔逊相关系数 $r$ 来判断:

$$
r=\frac{\sum x_{i} y_{i}-\frac{\sum x_{i} \sum y_{i}}{n}}{\sqrt{\sum x_{i}^{2}-\frac{\left(\sum x_{i}\right)^{2}}{n}} \sqrt{\sum y_{i}^{2}-\frac{\left(\sum y_{i}\right)^{2}}{n}}}
$$

式中, $r$ 为变量 $X$ 和 $Y$ 的相关关系, $x_{i}$ 和 $y_{i}$ 分别是两个变量 中的第 $i$ 个样本. 根据经验, 变量之间的相关程度可按 表1进行划分(贾俊平, 2014).

\section{3 结果与分析}

\section{1 中国陆地气候的平均干湿状况}

首先计算各气象站点的逐年 $E T_{0}$. 然后, 基于薄盘 光滑样条插值法(ANUSPLIN) 对 $E T_{0}$ 和降水量的站点 数据分别进行空间插值(Hutchinson, 2004), 数据空间 分辨率为 $0.1^{\circ}$. 利用实际值和拟合值之间的拟合优度 $\left(R^{2}\right)$ 来检验空间插值的效果, 结果显示 $E T_{0}$ 和降水量的 平均 $R^{2}$ 分别为 0.93 和 0.90 , 达到了高度拟合水平. 最 后, 利用式(1)计算得到1961 2015年气候干燥度指数 的平均格局. 按照郑度(2008)的干湿区划方法, 年干 燥度指数 $K$ 值与气候干湿类型的对应关系是: $K \leq 1.0$ 为 湿润气候; 1.0 1.5 为半湿润气候; $1.5 \sim 4.0$ (青藏高原为 1.5 5.0)为半干旱气候; $K \geq 4.0$ 为干旱气候(青藏高原为 $K \geq 5.0$ )(图1).

总体来看, 中国气候干燥程度自东南沿海向西北 内陆逐渐增加. 秦岭-淮河一线年降水量和 $E T_{\mathrm{o}}$ 大致相 等, $K$ 值大约为 1.0 , 这条线也被作为综合自然区划中 湿润区和半湿润区的界线(黄秉维, 1958). 但该线并不 具有几何意义, 而是一个过渡带, 且会随着气候变化 而发生位移. 在 20 世纪 80 年代以前此线位置略偏南, 而在 80 年代以后则略偏北(杨建平等, 2002; 市娟娟等, 2013). 该线以南、巴颜喀拉山和念青唐古拉山以东 的大部分地区 $K \leq 1.0$, 气候湿润. 但横断山脉及毗邻的 南北走向山系河谷地区 $K>1.0$, 原因是该区域位于纵

\section{表 1 相关系数与相关关系对应表}

\begin{tabular}{cc}
\hline 相关系数范围 & 相关关系 \\
\hline$|r|>0.95$ & 存在显著性相关 \\
$0.8<|r| \leq 0.95$ & 高度相关 \\
$0.5 \leq|r|<0.8$ & 中度相关 \\
$0.3 \leq|r|<0.5$ & 低度相关 \\
$|r|<0.3$ & 相关关系极弱, 一般认为不相关 \\
\hline
\end{tabular}




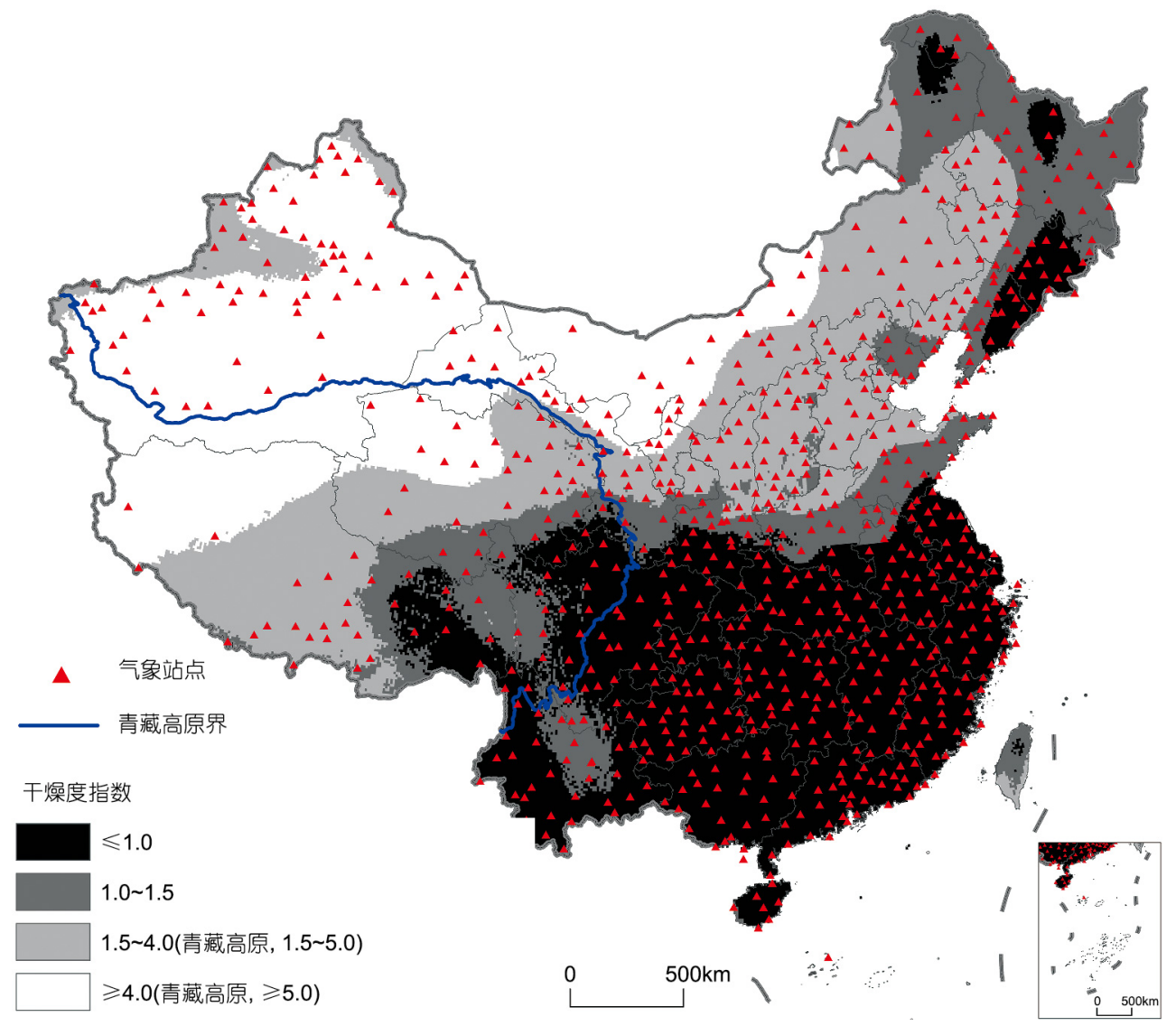

图 1 近 55 年中国陆地气候干燥度指数的平均状况

青藏高原边界参考张镱锂等(2002)

向岭谷区的北部, 两侧高䇯的山脉阻隔了东西方向的 水汽进入, 沿山间河谷北上的湿润气流成为该区域的 主要水汽来源, 然而在南低北高的地形影响下, 西南 季风和东南季风均由南向北减弱, 降水量较南部少. 加之河谷焚风效应和山谷风效应的影响, $E T_{\mathrm{o}}$ 较高(潘 蹈等, 2012), 导致了该区域的气候比东西两侧及南边 地区干燥. 除该区域以外, $K$ 值介于 $1.0 \sim 1.5$ 的半湿润区 域还包括黄淮地区、青藏高原东部高寒灌从和草甸 地区以及东北东部和北部地区等. 大兴安岭北部寒温 带地区、小兴安岭及长白山地区由于气候高寒, $E T_{\text {。 }}$ 较周边低, 使得这些区域 $K \leq 1.0$.

位于大兴安岭、阴山、贺兰山、祁连山和昆仑 山等山脉以北和以西的地区, 由于深居欧亚大陆腹地, 且周围大山脉阻断了季风气流的进入, 很难接收到来 自海洋的水汽, 降水量稀少, 年干燥度指数 $K \geq 4.0$ (青藏 高原 $K \geq 5.0)$, 气候干旱. 但新疆的伊犁河谷、塔城盆地
及阿勒泰地区在特殊地形的作用下, 截获了西风气流 中的水汽, 降水量较东部高, 年干燥度指数 $K<4.0$. 除这 些区域外, $K$ 值介于 $1.5 \sim 4.0$ (青藏高原为 $1.5 \sim 5.0$ ) 的半干 旱区域还包括松辽平原、内蒙古高原东部、华北平 原的黄河以北地区、黄土高原大部、青海三江源、 南差塘高原和藏南雅鲁藏布江中上游高山谷地等.

同样是临海的区域, 淮河以北的环渤海地区却不 如淮河以南的沿海地区湿润, 究其原因可能包括以下 3 个方面: (1) 渤海以东的海面 (大约 $41^{\circ} \mathrm{N} \sim 34^{\circ} \mathrm{N}$ ) 被朝鲜 半岛、日本列岛等大面积陆地间隔, 低空大洋水汽向 中国大陆的输送不够通畅. (2) 东亚夏季风是中国东 部地区的主要水汽来源, 而夏季风的进退有其阶段性, 不同的阶段对应不同区域的雨季期. 淮河以南地区的 雨季较长, 而淮河以北的华北和东北雨季则持续时间 较短(丁一汇等, 2013). (3) 青藏高原在夏季成为一个 巨大的热源, 其近地面形成热低压, 吸引着来自海洋上 
湿润气流, 使青藏高原以东、秦岭-淮河以南的亚热带 地区摆脱了副热带高压的控制, 气候湿润(赵济, 2012).

\section{2 中国气候干湿变化的总体趋势和周期性}

把各栅格年干燥度指数 $K$ 进行 $z$-score标准化之后, 求全国各年平均值、55年平均值和 11 年滑动平均值 (图2a). 并对各年平均值进行Morlet小波分析, 可得到 不同时间尺度的小波系数分布(图2b)和小波方差(图 2c). 小波系数为正时, 表明在以某个时间尺度为周期 的波动中全国气候整体偏干, 反之则表明气候偏湿.

干燥度指数各年平均值围绕 55 年平均值上下波 动, 气候干湿状况的线性变化趋势整体不显著(趋势 线 $\left.R^{2}=0.02\right)$. 气候干湿状况变幅较大的年份大多为厄 尔尼诺事件发生的年份, 如1965 1966年、1976 1977 年、1982 1983 年、1986 1987 年、1997 1998 年、 2001 2002年、2009 2010年、2014 2015年等, 这可 能跟厄尔尼诺对中国季风区气候变化影响显著有关 系(谭明, 2016). 11 年滑动平均值显示 20 世纪 80 年代 以前中国总体相对干燥, 在 80 年代以后则整体进入 一段相对湿润的时期，而且1987 1996年期间全国年 平均干燥度指数比 55 年平均值偏低(图 2a), 说明这十 年间全国的气候总体偏湿润. 吴绍洪等(2016)的研 究表明 20 世纪 60 年代以来, 中国气候总体上存在一 个相对冷的时段(1960 1986年)和一个相对暖的时段 (1987 2011年). 由此看来, 1987年前后可能是近五六
十年来中国气候特征的一个重要转折时期.

从小波分析来看 (图 $2 \mathrm{~b}$ 和 $\mathrm{c}$ ), 过去 55 年全国平均干 湿状况在不同时间尺度上表现的周期变化特征不同， 小尺度的干湿周期变化往往嵌套在大尺度的周期变 化之中. 小波方差的峰值主要有 4 个, 表明在 3 年、7 8 年、 11 年和 $26 \sim 28$ 年的时间尺度上, 气候干湿变化表 现出了较强的周期性, 其中小波方差最大的是 11年尺 度. 2015年的小波系数等值线在长周期和短周期上均 未闭合, 说明在 2015 年以后中国将处于干湿变化周期 中的偏干燥阶段, 这将会加剧水资源供需矛盾(Piao等, 2010), 对雨养农业产生负面影响(IPCC, 2014), 并且会 导致荒漠化面积扩大(苏志珠等, 2006).

\section{3 气候干湿变化趋势的区域差异}

把1961 2015年各栅格年干燥度指数作为因变量, 将其所对应的年份作为自变量, 利用最小二乘法进行 一元线性回归(显著性水平假设为 $\alpha=0.1$ ), 所得直线斜 率的 10 倍即为过去 55 年干燥度指数的气候倾向率, 用 该气候倾向率除以栅格年干燥度指数 55 年平均值可 以视为区域干湿状况的十年平均变化率(图3a). 回归 方程 $\mathrm{F}$ 检验的统计显著性 $p$ 值代表年干燥度指数存在 线性变化趋势的显著程度, $p$ 值越小统计越显著, 反之 则越不显著, 当 $p$ 值高于假设的显著性水平 0.1 时, 统计 不显著(图3b).
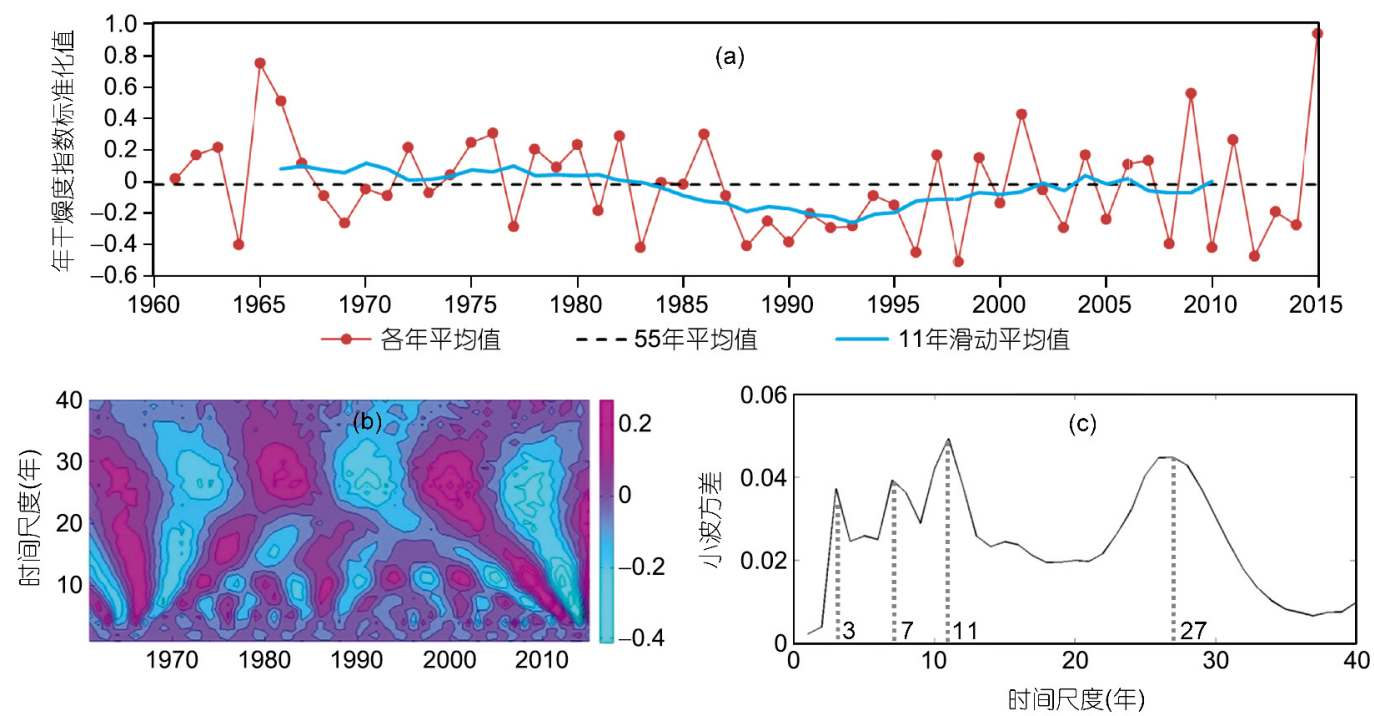

图 2 全国平均年干燥度指数波动情况(a)及不同时间尺度小波系数(b)和小波方差(c) 

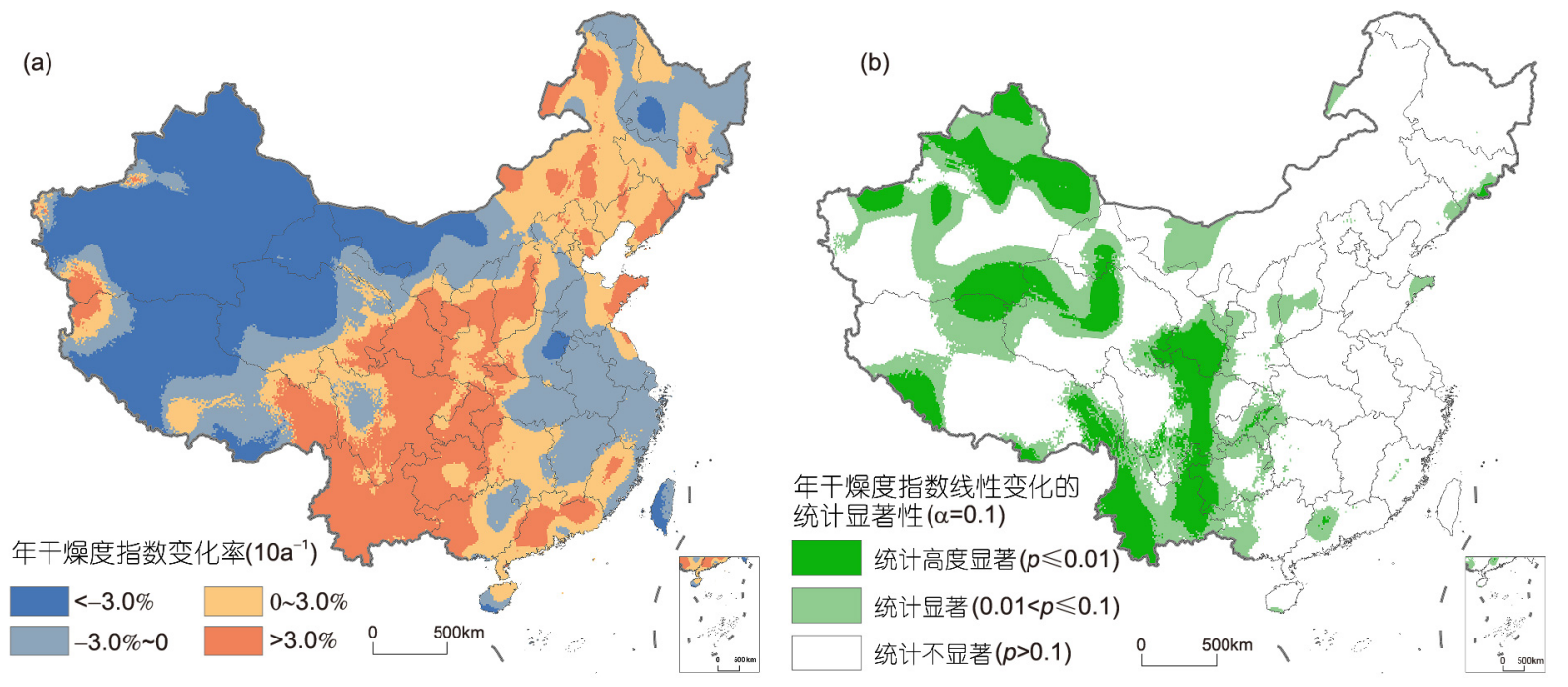

图 3 年干燥度指数变化率(a)及线性变化趋势的统计显著性(b)

从年干燥度指数的变化率来看(图3a), 1961 2015 年中国陆地气候湿润程度平均增加的区域主要包括 西北和青藏高原的大部分地区、东北北部地区和华 东大部分地区, 占国土面积的 $46.4 \%$, 其余部分的气候 则干燥程度平均增加. 其中西北和青藏高原西部等地 区气候湿润程度增加幅度较大, 而云贵高原、四川盆 地和黄土高原等地区则气候干燥程度增加幅度较大. 这与部分相关研究的结果相近, 如杨建平等(2002)和 廖要明和翟盘茂(2014)的研究显示西北地区的气候干 燥程度有所缓解、毛飞等(2008)发现青藏高原大部分 地区湿润度在增加、申双和等(2009)认为四川盆地的 气候干燥度增加明显. 但图 $3 b$ 显示干燥度指数线性变 化趋势显著 $(p \leq 0.1)$ 的区域面积仅占全国的 $34.3 \%$ (线性 趋势高度显著的占 $14.0 \%)$, 这说明过去 55 年中国大部 分地区气候干湿变化的非线性特征更加突出. 湿润程 度线性增加趋势显著的区域主要包括北疆大部分地 区、昆仑山东部地区和祁连山西部地区等, 而云贵高 原、成都平原及陇南山区等的气候干燥程度呈显著 线性增加趋势.

\section{4 气候干湿变化周期的区域差异}

区域气候变化在时间上具有多尺度特性, 气候的 干湿变化也同时存在较短和较长时间尺度的周期性. 对各栅格年干燥度指数进行 z-score标准化之后, 求其 小波方差曲线的极大值, 若干个极大值对应气候干湿 变化多个时间尺度的周期(图4).
小波方差越大, 在其所对应的时间尺度上气候干 湿变化的周期性就越强. 1961 2015年中国大部分区 域气候干湿变化在8 14年的尺度上周期性较强(图4b), 特别是在大兴安岭以西地区、松辽平原、贺兰山及 周边地区、内蒙古高原、黄土高原以及南疆等区域. 东北三江平原、长白山区、长江下游地区、粤桂丘 陵山地及琼雷台地、青藏高原西部地区、伊犁河谷 及塔城盆地等地区的气候干湿变化在15 21年的尺度 上节律性较强(图4c). 华北平原、辽河平原、横断山 脉、祁连山南部、青海湖流域及北疆等区域则更多的 在22 28年时间尺度上表现出较强的干湿变化周期规 律(图4d). 此外, 中国大部地区的气候干湿变化在3 7 年的较短时间尺度上也表现出一定的周期性(图4a).

\section{4 讨论}

\section{1 气候干湿变化的主导因子分析}

把近 55 年来各栅格气候干燥度指数跟与其密切 相关的气候因子进行相关分析(式(6)), 相关系数绝对 值越大, 说明气候干湿状况受该因子的影响也越大. 本文将与干燥度指数相关系数绝对值最大的那个因 子看作气候干湿变化的第一主导气候因子(图 5a), 相 关系数绝对值第二大的那个因子则看作第二主导气 候因子(图5b).

1961 2015年中国陆地大部分区域的气候干湿变 化第一主导因子是年降水量(图5a), 所以有学者只利 

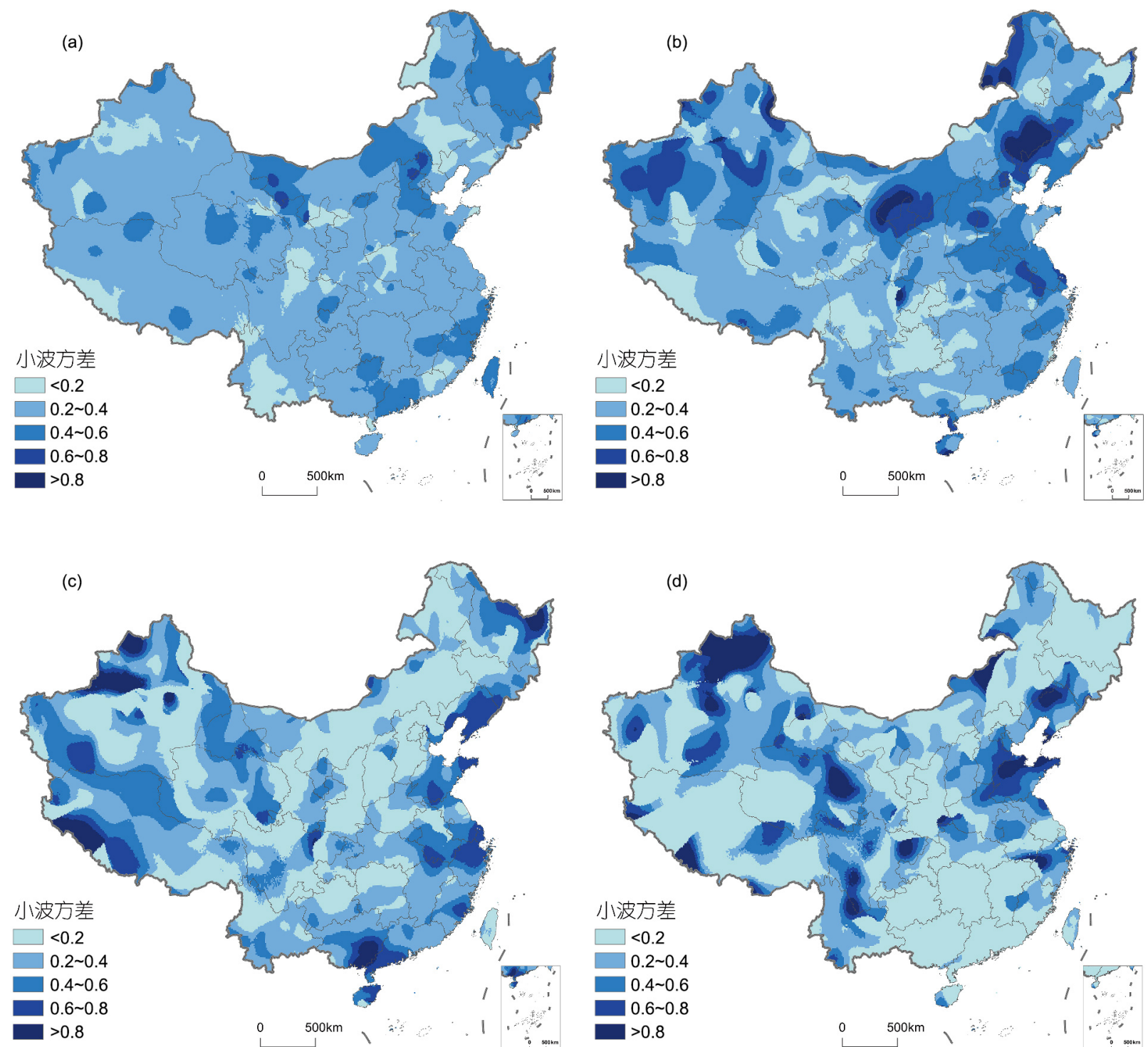

(c)

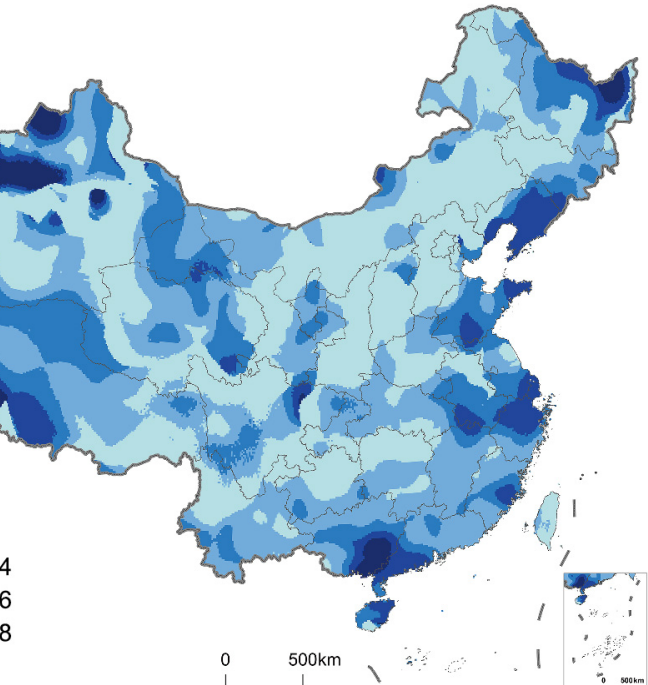

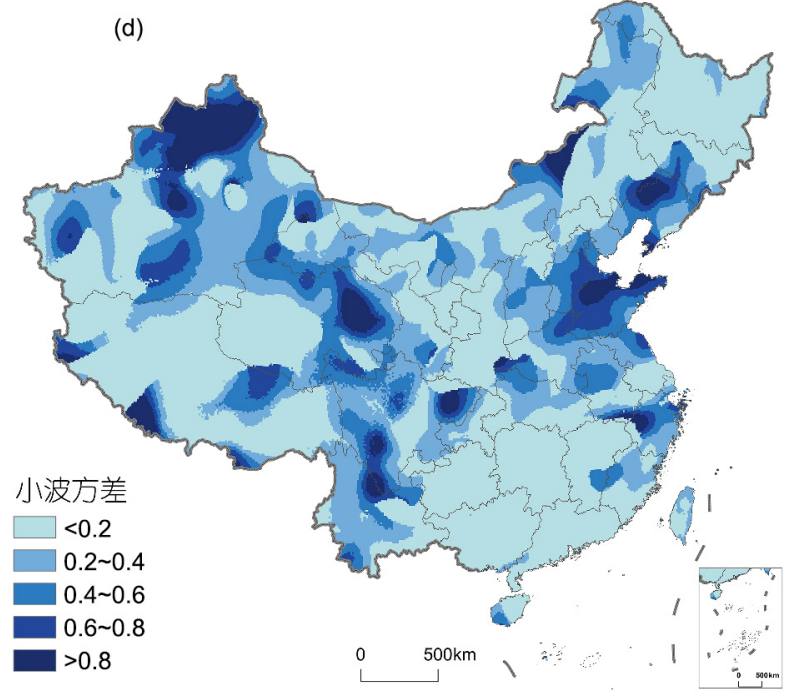

图 4 年干燥度指数不同变化周期所对应的小波方差 (a) 3 7年, (b) 8 14年, (c) 15 21年, (d) 22 28年

用年降水量单个气候因素来研究中国气候干湿状况, 并进行干湿气候区划(Wu等, 2003)和干湿变化区划(史 培军等, 2014). 尤其在中国北方地区, 年干燥度指数与 降水量的相关系数绝对值 $|r|$ 大多介于 $0.8 \sim 0.95$ (图 5c), 二者达到高度相关(表1). 有学者分别利用降水量与 $E T_{0}$ 之比的综合指标和降水量单因素指标在北方地区 进行干湿气候区划, 结果显示二者的差异并不大(王菱 等, 2004). 文中图 $2 b$ 显示中国大部分区域气候干湿变 化的线性趋势不显著, 这与降水量的线性变化不显著 有较大关系(IPCC, 2013).
但影响气候干湿状况的不仅只有降水量, 图 $5 \mathrm{~b}$ 和 $\mathrm{d}$ 显示相对湿度、温差、日照时数和温度等因子对不 同区域的干湿变化也产生较大的影响. 其中干湿变 化受相对湿度影响较大的区域主要包括北方和西南 的大部分地区, 与干燥度指数的相关系数 $r$ 大多介于 $-0.5 \sim-0.8$, 为中度负相关. 干湿状况受温差影响较大 的区域主要有青海三江源、江淮流域以及秦巴山脉 等地区, $r$ 大多介于 $0.5 \sim 0.8$, 为中度正相关. 东北北部、 华南及江苏大部分区域的气候干湿变化受日照时数 影响较大, $r$ 同样大多介于 $0.5 \sim 0.8$, 为中度正相关. 四 

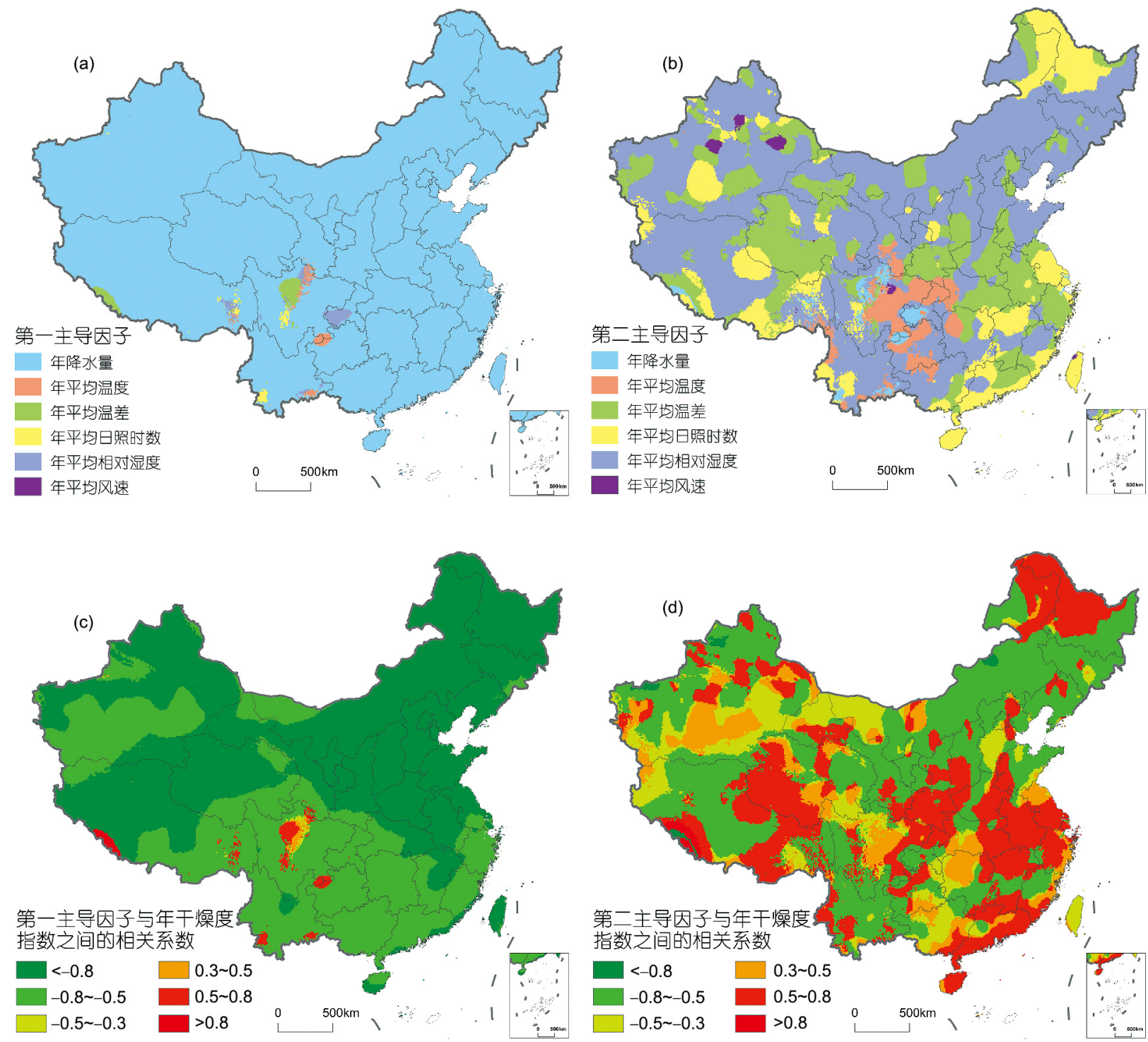

图 5 气候干湿变化的主导气候因子 $((\mathbf{a})$ 和 $(\mathbf{b}))$ 及其与年干燥度指数的相关关系 $((\mathbf{c})$ 和 $(d))$

川盆地的大部分区域气候干湿状况受到气温的影响, $r$ 大多介于 $0.5 \sim 0.8$.

\section{2 不确定性分析}

文中所分析的空间数据分辨率为 $0.1^{\circ}$ (面积约为 $\left.100 \mathrm{~km}^{2}\right)$, 这对于地形复杂区域来说, 每个栅格的 $E T_{\mathrm{o}}$ 、 $K$ 值等可以代表该网格的平均状态, 但若要反映栅格 内更小尺度的空间差异, 则需要更密集气象站点支撑 下的更高分辨率研究. 此外, 气象站点并非在全国均 匀分布, 如在青藏高原西部地区的站点分布较少, 而
台湾地区没有分布, 使上述两个区域的数据精度和研 究结果的准确性受到一定影响.

气候变化周期在时间上具有多尺度特征, 短到以 日为周期的昼夜变化, 或者以年为周期的季节变化, 长到几百年甚至上千年的周期变化(葛全胜等, 2012). 本研究讨论了1961 2015年中国陆地气候干湿状况的 年际变化周期, 在这 55 年的时间段中能够较为准确的 判断出小于 28 年的波动周期, 但并不意味着气候干湿 变化的周期仅限于 28 年以内, 更长时间尺度的干湿周 期研究将依赖于长时间序列的气候数据分析. 


\section{5 结论}

本文基于全国基本、基准气象站数据, 利用干燥 度指数分析了中国陆地1961 2015年气候干湿状况的 时空分异规律, 并讨论了干湿变化的主导气候因子, 得到的主要结论如下:

(1) 秦岭-淮河一线年降水量和潜在蒸散量 $E T_{0}$ 大 致相等, 该线以南、横断山脉以东的大部分区域降水 量高于 $E T_{\mathrm{o}}$, 气候湿润; 西北内陆地区降水量远小于 $E T_{\mathrm{o}}$, 气候干燥. 1961 2015年, 全国气候干湿状况的线性变 化趋势总体不显著, 干湿波动较大的年份大多为厄尔 尼诺事件发生的年份, 其中1987 1996年是全国气候 总体相对湿润的时期. 在这 55 里全国平均干湿状况在 3 年、 $7 \sim 8$ 年、 11 年和 $26 \sim 28$ 年的时间尺度上表现出了 较强的周期性.

(2) 中国气候干湿变化趋势及周期性区域差异明 显. 西北和青藏高原西部等地区气候湿润程度增加幅 度较大, 而云贵高原、四川盆地和黄土高原等地区气 候干燥程度增加幅度较大, 但中国大部分区域气候干 湿变化的线性趋势不显著. 中国大部分地区气候干湿 变化在8 14年的周期上表现出较强的节律性, 部分区 域还在15 28年尺度上周期性较强.

(3) 降水量是中国陆地大部分区域气候干湿变化 的主要影响因素, 特别在北方地区气候干湿变化与降 水量高度相关. 此外, 北方和西南大部分地区的气候 干湿状况还与空气相对湿度有较强相关性, 温差对三 江源、江淮流域以及秦巴山脉等地区的干湿状况也 有较显著影响, 东北北部、华南及江苏大部分区域的 气候干湿变化受日照时数影响较大.

\section{参考文献}

市娟娟, 郝志新, 郑景云, 葛全胜, 尹云鹤. 2013. 1951 2010年中国 主要气候区划界线的移动. 地理研究, 32: 1179-1187

丁一汇, 王绍武, 郑景云, 王会军, 杨修群. 2013. 中国自然地理系列 专著: 中国气候. 北京: 科学出版社. 557

方修琦, 陈发虎. 2015 . 植物物候与气候变化. 中国科学: 地球科学, 45: 707-708

葛全胜, 郑景云, 郝志新, 刘浩龙. 2012. 过去2000年中国气候变化 的若干重要特征. 中国科学: 地球科学, 42: 934-942

黄秉维. 1958. 中国综合自然区划的初步草案. 地理学报, 24: 14-31 贾俊平. 2014. 统计学基础(第2版). 北京: 中国人民大学出版社. 305 廖要明, 翟盘茂. 2014. 中国气候区划与气候图集方案研究. 北京:
气象出版社. 173

马柱国. 2005. 我国北方干湿演变规律及其与区域增暖的可能联系. 地球物理学报, 48: 1011-1018

毛飞, 唐世浩, 孙涵, 张佳华. 2008. 近46年青藏高原干湿气候区动 态变化研究. 大气科学, 32: 499-507

潘蹈, 吴绍洪, 何大明, 戴尔阜, 刘玉洁. 2012. 纵向岭谷区地表格局 的生态效应及其区域分异. 地理学报, 67: 13-26

气候变化国家评估报告编写委员会. 2015. 第三次气候变化国家评 估报告. 北京: 科学出版社. 976

申双和, 张方敏, 盛琼. 2009. 1975 2004年中国湿润指数时空变化 特征. 农业工程学报, 25: 11-15

史培军, 孙劭, 汪明, 李宁, 王静爱, 金斑望, 顾孝天, 尹卫霞. 2014 . 中国气候变化区划(1961 2010年). 中国科学: 地球科学, 44: 2294-2306

苏志珠, 卢琦, 吴波, 靳鹤龄, 董光荣. 2006. 气候变化和人类活动对 我国荒漠化的可能影响. 中国沙漠, 26: 329-335

谭明. 2016. 近千年气候格局的环流背景: ENSO态的不确定性分析 与再重建. 中国科学: 地球科学, 46: 657-673

王菱, 谢贤群, 李运生, 唐登银. 2004. 中国北方地区40年来湿润指 数和气候干湿带界线的变化. 地理研究, 23: 45-54

王延禄. 1990. 我国建立、引用和验证气象干旱指标综述. 干旱区 地理, 13: 80-86

王铮, 乐群, 夏海斌, 孙翊, 钟章奇, 徐程瑾, 顾高翔, 王远飞. 2016 . 中国 2050: 气候情景与胡焕庸线的稳定性. 中国科学: 地球科学, 46: $1505-1514$

吴绍洪, 尹云鹤, 郑度, 杨勤业. 2005. 近30年中国陆地表层干湿状 况研究. 中国科学D辑: 地球科学, 35: 276-283

吴绍洪, 刘文政, 潘韬, 邓浩宇, 焦珂伟, 尹云鹤. 2016. 1960 2011年 中国陆地表层区域变动幅度与速率. 科学通报, 61: 2187-2197

吴绍洪, 潘韬, 刘燕华, 邓浩宇, 焦珂伟, 陆晴, 冯爱青, 岳溪柳, 尹云 鹤, 赵东升, 高江波. 2017. 中国综合气候变化风险区划. 地理学 报, 72: 3-17

杨建平, 丁永建, 陈仁升, 刘连友. 2002. 近50年来中国干湿气候界 线的 10年际波动. 地理学报, 57: 655-661

尹云鹤, 吴绍洪, 郑度, 杨勤业. 2005. 近30年我国干湿状况变化的 区域差异. 科学通报, 50: 1636-1642

苑全治, 吴绍洪, 戴尔阜, 赵东升, 任平, 张学儒. 2016. 过去50年气 候变化下中国潜在植被NPP的脆弱性评价. 地理学报, 2016, 71: 797-806

岳平, 张强, 赵文, 王润元, 张良, 王文玉, 史晋森, 郝小翠. 2015. 黄 土高原半干旱草地生长季干湿时段环境因子对陆面水、热交换 的影响. 中国科学: 地球科学, 45: 1229-1242

张强, 张良, 黄菁, 张立阳, 王文玉, 沙莎. 2014. 我国黄土高原地区陆 面能量的空间分布规律及其与气候环境的关系. 中国科学: 地 球科学, 44: 2062-2076

张镱锂, 李炳元, 郑度. 2002. 论青藏高原范围与面积. 地理研究, 21: 
$1-8$

赵济. 2012. 中国自然地理(第3版). 北京: 高等教育出版社. 342 郑度. 2008. 中国生态地理区域系统研究. 北京: 商务印书馆. 387 郑景云, 尹云鹤, 李炳元. 2010. 中国气候区划新方案. 地理学报, 65: 3-12

Allen R G, Pereira L S, Raes D, Smith M. 1998. Crop Evapotranspiration: Guidelines for Computing Crop Water Requirements. FAO Irrigation and Drainage Paper No. 56. Rome: United Nations Food and Agriculture Organization. 300

Budyko M H. 1974. Cimate and Life. New York: Academic Press. 508

Fisher J B, DeBiase T A, Qi Y, Xu M, Goldstein A H. 2005. Evapotranspiration models compared on a Sierra Nevada forest ecosystem. Environ Model Softw, 20: 783-796

Gurtz J, Baltensweiler A, Lang H. 1999. Spatially distributed hydrotope-based modelling of evapotranspiration and runoff in mountainous basins. Hydrol Process, 13: 2751-2768

Holdridge L R. 1947. Determination of world plant formations from simple climatic data. Science, 105: 367-368

Hutchinson M F. 2004. ANUSPLIN Version 4.3 User Guide
IPCC. 2013. Climate Change 2013: The Physical Science Basis. Cambridge: Cambridge University Press. 1535

IPCC. 2014. Climate Change 2014: Impacts, Adaptation, and Vulnerability. New York: Cambridge University Press. 1820

Monteith J L. 1981. Evaporation and surface temperature. Q J R Meteorol Soc, 107: 1-27

Penman H L. 1948. Natural evaporation from open water, bare soil and grass. Proc Royal Soc London, 193: 454-465

Piao S, Ciais P, Huang Y, Shen Z, Peng S, Li J, Zhou L, Liu H, Ma Y, Ding Y, Friedlingstein P, Liu C, Tan K, Yu Y, Zhang T, Fang J. 2010. The impacts of climate change on water resources and agriculture in China. Nature, 467: 43-51

Thornthwaite C W. 1948. An approach toward a rational classification of climate. Geograph Rev, 38: 55-94

Wu S H, Yang Q Y, Zheng D. 2003. Delineation of eco-geographic regional system of China. J Geogr Sci, 13: 309-315

Yin Y, Wu S, Zheng D, Yang Q. 2008. Radiation calibration of FAO56 Penman-Monteith model to estimate reference crop evapotranspiration in China. Agric Water Manage, 95: 77-84 